\title{
Guest Service Management and Processes in Restaurants: What We Have Learned in Fifty Years
}

Cornell Hospitality Quarterly

$5 \mathrm{I}$ (4) 479-482

(C) The Author(s) 2010

Reprints and permission:

sagepub.com/journalsPermissions.nav DOI: $10.1177 / 1938965510375028$

http://cqx.sagepub.com

@SAGE

\section{By Alex M. Susskind}

\begin{abstract}
Although restaurant-related research has long focused on boosting sales, the focus on revenue as a quantitative discipline has arisen only in the past fifteen years, with restaurant revenue management. This series of studies is emblematic of the increased focus on scientific studies to help restaurateurs improve their operations. Another thread of research, on service process management, included a series of articles explaining the many elements beyond the food itself that go into a successful restaurant operation. A particular element in guest satisfaction is the extent to which employees believe that their restaurant maintains service standards. Finally, when service goes awry, service recovery requires handling guest complaints in a prompt and appropriate fashion. Service failures subject restaurants to negative word of mouth, but it is not simply a matter of a dissatisfied guest complaining to a certain number of friends. Instead, the nature and number of subsequent negative comments depends on the type of failure - with food quality being most critical.
\end{abstract}

\section{Keywords}

restaurant management; service process management; revenue management; guest complaints

We have certainly come a long way. Although I was not yet born as the first issue of the Cornell Hotel and Restaurant Administration Quarterly (now the Cornell Hospitality Quarterly, or $C H Q$ ) was published, I know that the world was a different place and the food-service industry most definitely had a different landscape. At the time of the first issue in 1960, McDonald's was a small but growing chain purchased by Ray Kroc only five years earlier, and the largest chain restaurant company in the United States was operated by Howard Johnson. Thus, people were more familiar with orange roofs than with golden arches. Influential chain restaurateurs like Norman Brinker, Bill Darden, Chris Sullivan, and Paul Fleming had yet to make their mark in the restaurant business, and many of the celebrity chefs and restaurateurs who have revolutionized restaurant dining as we all know it today, such as Wolfgang Puck, Tom Colicchio, Danny Meyer, and Drew Neiporent (to name a few) were children. French cuisine ruled as the standard for the "best" restaurants. We had not yet seen or heard of molecular gastronomy, upscale casual dining, fast casual dining, or transfat-free anything, or, for that matter, fat-free anything. Fifty years later, McDonald's is one of the largest restaurant companies in the world, Howard Johnson's restaurants have disappeared, America's cuisine has stepped up to match that of France, and the world of restaurants now seems boundless.
In this article I am going to discuss several of the major themes and advances we have seen over the years in the restaurant industry through the work published in the $C H Q$. In doing so, I will address two main areas: service process management (including complaint management) and operational performance. Before I move into the main part of the discussion of service process management and complaint management, I will highlight two studies in the $C H Q$ that I believe have been instrumental in providing operators and academics alike valuable insight into how our industry works and offer ways to improve practice.

First, prior to 1998, the terms "restaurant revenue management" and "revenue per available seat hour" (RevPASH) did not exist. In ground-breaking work in the $C H Q$, Professor Sherri Kimes and her colleagues applied the principles of yield management from the hotel and airline segments of our business to introduce the topic and start a line of research and a set of operations-based tools to better analyze, manage, and control revenue flow in restaurants (Kimes et al. 1998). Through her work, Kimes demonstrated that by using a quantitative approach to examining operational and service processes, you can identify operational areas needing improvement. This requires a blend of scientific management, optimization, a keen understanding of how your operation works, and knowing your guests' attitudes and preferences regarding their service experiences. As I explain 
further in a moment, the key is to keep all these factors in view, as focusing on one area alone is never sufficient. Since then, $C H Q$ has published well over thirty articles that have built on the concept of restaurant revenue management (cf. Noone et al. 2007; Susskind, Reynolds, and Tsuchiya 2004).

In 2005, H. G. Parsa and his colleagues set out to debunk the commonly repeated myth that between 80 and 90 percent of independent restaurants fail in their first year. Through their work, they identified the key characteristics behind restaurant success and failure and provided a thorough analysis of what actually happened in our business from 1990 to 1999. Studying a large Ohio market, they found that only 26.16 percent of independent restaurants failed during the first year of operations - quite a difference from the conventional wisdom. Parsa et al. concluded that internal factors such as strategy, culture, and operational and management savvy had a stronger influence on restaurant success than did external factors such as demographics and social and competitive forces - but all do matter in the long run. In short, having sufficient cash flow is important, but that alone is not enough to succeed, just like having a great concept or location is also important but not sufficient. In their article, Parsa et al. clearly demonstrate how restaurant success or failure is a confluence of internal factors, external factors, organizational life cycle, and the structure and state of the restaurateur's family life. Another myth debunked by the $C H Q$ !

\section{Service Process Management and Guest Satisfaction}

The $C H Q$ has published many articles that have helped us better understand service process and how to manage themall with a goal of improving guest satisfaction. In 1970, Michael Hurst wrote an article titled "You Sell More than Food," which has resonated with me strongly over the years. He talks about how a restaurant experience is created, and he highlights all of the details and factors that influence the guest's experience, using Win Schuler's restaurants as examples. He articulates what I like to refer to as the "Big Three Ps": people, product, and (operational) processes. He highlights that atmosphere is just as important as the food, arguing that the food just will not taste as good as it could if the atmosphere is not seasoned with good, caring service providers. He further notes that management is principally responsible for setting the tone, as they hire the people who interact with the guests at all levels. The stage is set by management, and the show is created for the guests.

Many subsequent $C H Q$ articles built on this idea, such as "Managing the Service Encounter," by Mill in 1986; "Ten Laws of Customer Satisfaction," by Knutson in 1988-1989; “"Restauration' Theater: Giving Direction to Service," by Romm in 1989; "Restaurant Service: Making Memorable Presentations," by Meyers in 1991;
"The 'WOW' Effect," by Barry Cohen in 1997; and "Managing Your Guest as a Quasi-Employee" by Ford and Heaton in 2001.

A relatively recent article in this thread was "The Combined Effects of the Physical Environment and Employee Behavior on Customer Perception of Restaurant Service Quality," by Wall and Berry in 2007. Thirty-seven years after Hurst's article was presented in the $C H Q$, Wall and Berry further demonstrate that it is important to manage the functional, mechanic, and humanic cues in a restaurant environment to create guest satisfaction. In all of these articles, the authors clearly defined and differentiated the distinctive elements that make up restaurant experiences and offered real insight and tools to better manage guest experiences.

\section{Guest-Server-Exchange}

In an attempt to better explain the connection between line-level employees, managers, and guests in restaurants, two coauthors and I (Michele Kacmar and Carl Borchgrevink) published the Guest-Server-Exchange model (GSX) in the $C H Q$ (Susskind, Kacmar, and Borchgrevink 2007). In this model we proposed and tested the connection between guest satisfaction and employees' view of their workplace - that is, are standards in place, do employees receive adequate support from their coworkers and supervisors to perform their duties, and do employees have a guest orientation? We found that employees who reported that they believed their organization had a high level of standards in place also reported that they received a high level of support from their coworkers and supervisors and reported a high level of guest orientation. In the model a high level of guest orientation was associated with higher levels of guest satisfaction. So the GSX model demonstrated a strong connection between organizational elements and processes, employee behavior, and guest outcomes. This research and several other studies (cf. Ghiselli, La Lopa, and Bai 2001) highlight the importance of creating a culture for service that will permeate all the constituents of the restaurant (that is, managers, owners, guests, and employees).

\section{Complaints and Complaint Management}

In 1987, Martin Moser wrote a great article titled "Answering the Customer's Complaint: A Case Study," which presented an actual guest complaint letter from the "Loflin" family and the "Retreat House's" response to the complaint, along with commentary from several seasoned operators. What made this article so influential was that it demonstrated how to dissect a complaint letter, how to respond to guests (or how not to respond), and how to avoid some common pitfalls in managing guest complaints. Moser suggests doing the following: (1) take ownership of the problem 
or issue and sincerely apologize; (2) recognize the amount of time it takes the guest to complain and to properly resolve complaints from the operator's view; (3) focus on trying to understand the issue from the guest's perspective; (4) offer the guest a relevant explanation of what happened, but never give excuses; (5) offer an agreeable remedy to the guest; and (6) follow up with the guest to make sure that the remedy and recovery process met or exceeded the guest's expectations.

All of these principles still apply to complaint management today, but there are some new wrinkles. In 1986 - when the Loflins made their complaint-we did not have e-mail, company webpages, or social media sites. At that time, old-fashioned, handwritten or typewritten complaint letters were a common mode of complaint communication, along with telephone calls (using what is now known as a landline). Operators today still need to deal with written complaints from guests; they just may not arrive in a stamped envelope delivered by a mail carrier a week after the service failure occurred.

Nevertheless, the lessons transcend time and technology. First, in this case, the guests had already concluded their service experience and had left the restaurant grossly unsatisfied. What this means is that the problems they experienced (and other guests too) went virtually unnoticed by the operator. The operator lost the opportunity to make the Loflins happy before they left; we all know how much more difficult service recovery becomes after the guest leaves your restaurant. A good server and manager, regardless of staffing levels, should be able to identify guests who are being well served and guests who are not. It is management's responsibility to know what is transpiring in the restaurant, period. Glenn Withiam mirrored these comments in his 1987 CHQ editorial "The Inefficiencies of Service," noting that management needs to control the service experience for both guests and employees. Lewis and Morris, in "The Positive Side of Guest Complaints" (1987), highlighted that guest complaints help identify problems for managers and can help them improve their service delivery. Managers should be proactive in soliciting feedback from guests to continuously improve their performance in the marketplace (Daltas 1977; Lewis and Pizam 1981). The key challenge to guest feedback is that you really only get one chance to get it right, or risk losing the guest forever.

Second, the idea of service recovery and compensation is a simple one. Following a service failure, ask the guest what will make him or her happy. You will be pleasantly surprised that your guests will normally ask for much less than you are prepared to offer them. Give the guest the opportunity to decide what will remedy the situation for him or her. Offering a predetermined remedy like a free dessert, appetizer, or glass of wine sends the wrong message, because your guests may not want those remedies. Keep in mind that although you will from time to time have to deal with what may seem like an unreasonable compensation request from a guest, these requests are rare and are part of the cost of doing business and making mistakes in service delivery. This idea was presented by Shimko (1994), who advocated giving managers and servers the freedom to resolve complaints as they arise- even outside of the rules. This idea has been applied with positive results in many contexts. For example, YUM! Brands and Ritz-Carlton give employees discretion in how to solve guest complaints. In some instances, employees have $\$ 1,000$ at their disposal per service episode to resolve complaints or service failures for guests. This practice empowers line-level employees to identify and resolve problems for guests as they arise. It does not, however, alleviate management's responsibility to manage the service environment.

You should also be aware of the real costs associated with complaint remedies. Take the Loflins' case again, as outlined by Moser (1987). Here, you have four guests who dined in a restaurant, all of whom were unhappy, particularly the host. Let us assume the check for their dinner was $\$ 75.00$ per person, or $\$ 300.00$ plus tax and tip. The restaurant is open; the heat, lights, and equipment are on; and the staff is being paid. These are all sunk costs for the day. Although those costs are real enough, the out-of-pocket or marginal cost of this transaction equals the variable costs, that is, the food, beverage, and direct operating expenses associated with the meal. For argument's sake, let us say that these variable expenses are 40 percent. So, to "comp" the Loflins' whole $\$ 300.00$ meal would cost $\$ 120.00$. If the Loflins were pleased with how the complaint was handled and the remedy, you should be able to regain their trust and keep them as guests who will return in the future. Moreover, if this expense is "charged" against the process of learning from failures and preventing them reoccurring, the expense of complaint management should be lower for you in the long run. By contrast, if all you are doing is comping meals, you are missing the point.

Did the Loflins ever go back to the Retreat House? My guess is no, but there is also no indication that they told ten people about their problem, as is indicated in the commonly repeated idea that an unhappy guest tells an average of ten people about their problem. In 2002, a study I published in the $C H Q$ examined word-of-mouth (WOM) behavior among guests who experienced a service failure while dining in a full-service restaurant. What the study found was that the old adage was false (Susskind 2002). Instead, the study showed that WOM communication varied depending on the type of negative experience encountered by the guests. That is, all else being equal, guests were much more forgiving of the service-related failures they experienced during their meal compared to problems relating to food. Guests who reported problems with their food engaged in significantly more WOM communication compared to those who had problems with the service or their server. The study further identified that there were two other mitigating factors that lead to lower (or higher) levels of WOM 
communication: (1) how the complaint was handled or addressed, and (2) whether the guest intended to return to the restaurant. In that same article, I challenged the idea of the guest always being right when it comes to dealing with service failures.

What I reported then and still firmly believe is that it does not matter who is right when a service failure occurs. What matters is that you figure out what happened and why, solve the problem for the guest in the short term, and hopefully eliminate the possibility that the problem will occur again in your restaurant. Spending one second of time assigning blame is a second lost in the service-recovery process. This idea was not new in 2002, however. In 1984, a Wall Street Journal editorial titled "Service with a Smile? Not by a Mile," by Jim Mitchell, was reprinted in the $C H Q$. In his piece, he notes the old maxim "the customer is always right" has transformed into "the customer is a nuisance." As an example, he cites the classic Jack Nicholson scene in Five Easy Pieces, where Nicholson goes on a tirade in a café when he cannot get plain toast (without chicken). Another movie reference applies here, a quote from Godfather II, where the old gangster Hyman Roth (played by Lee Strasberg) tells a young Don Michael Corleone (played by Al Pacino), "This is the business you have chosen," in reference to conflict they were having over their business interests.

In conclusion, I agree with Hyman Roth. This is the business we have chosen. The $C H Q$ has helped us better understand the business we are in and how it has evolved over a half century. The more we can help our colleagues understand restaurant management, the better off we will be.

\section{References}

Cohen, Barry. 1997. The "WOW" effect, how one restaurateur continues to delight customers. Cornell Hotel and Restaurant Administration Quarterly 38:74-81.

Daltas, Arthur J. 1977. Protecting service markets with customer feedback. Cornell Hotel and Restaurant Administration Quarterly 18:73-77.

Ford, Robert C., and Cherrill P. Heaton. 2001. Managing your guest as a quasi-employee. Cornell Hotel and Restaurant Administration Quarterly 42:46-55.

Ghiselli, Richard F., Joseph M. La Lopa, and Billy Bai. 2001. Job satisfaction, life satisfaction, and turnover intent. Cornell Hotel and Restaurant Administration Quarterly 42:28-37.

Hurst, Michael E. 1970. You sell more than food. Cornell Hotel and Restaurant Administration Quarterly 11:103-4.

Kimes, S. E., R. B. Chase, S. Choi, P. Y. Lee, and E. N. Ngonzi. 1998. Restaurant revenue management: Applying yield management to the restaurant industry. Cornell Hotel and Restaurant Administration Quarterly 39:32-39.

Knutson, Bonnie J. 1988-1989. Ten laws of customer satisfaction. Cornell Hotel and Restaurant Administration Quarterly 29: 14-17.
Lewis, Robert C., and Susan V. Morris. 1987. The positive side of guest complaints. Cornell Hotel and Restaurant Administration Quarterly 27:13-15.

Lewis, Robert C., and Abraham Pizam. 1981. Guest surveys: A missed opportunity. Cornell Hotel and Restaurant Administration Quarterly 22:37-44.

Meyers, Don. 1991. Restaurant service: Making memorable presentations. Cornell Hotel and Restaurant Administration Quarterly 32:69-73.

Mill, Robert C. 1986. Managing the service encounter. Cornell Hotel and Restaurant Administration Quarterly 26:39-46.

Mitchell, Jim. 1984. Service with a smile? Not by a mile. Cornell Hotel and Restaurant Administration Quarterly 25:6.

Moser, Martin R. 1987. Answering the customer's complaint: A case study. Cornell Hotel and Restaurant Administration Quarterly 28:10-15.

Noone, Breffni M., Sheryl E. Kimes, Anna S. Mattila, and Jochen Wirtz. 2007. The effect of meal pace of customer satisfaction. Cornell Hotel and Restaurant Administration Quarterly 48:231-45

Parsa, H. G., John T. Self, David Njite, and Tiffany King. 2005. Why restaurants fail. Cornell Hotel and Restaurant Administration Quarterly 46:304-22.

Romm, David. 1989. "Restauration" theater: Giving direction to service. Cornell Hotel and Restaurant Administration Quarterly 29:31-39.

[Editor's Comment]. 1990. Cornell Hotel and Restaurant Administration Quarterly 31:117.

Shimko, Barbara Whitaker. 1994. Breaking the rules for better service. Cornell Hotel and Restaurant Administration Quarterly 35:18-22.

Susskind, Alex M. 2002. I told you so! Restaurant customers' wordof-mouth communication patterns. Cornell Hotel and Restaurant Administration Quarterly 43:75-85.

Susskind, A. M., M. K. Kacmar, and C. P. Borchgrevink. 2007. How organizational standards and coworker support improve restaurant service. Cornell Hotel and Restaurant Administration Quarterly 48:370-79.

Susskind, A. M., D. Reynolds, and E. Tsuchiya. 2004. An evaluation of guests' preferred incentives to shift time-variable demand in restaurants. Cornell Hotel and Restaurant Administration Quarterly 45:68-84.

Wall, Eileen A., and Leonard L. Berry. 2007. The combined effects of the physical environment and employee behavior on customer perception of restaurant service quality. Cornell Hotel and Restaurant Administration Quarterly 48:59-69.

Withiam, G. 1987. The inefficiencies of service [Editor's Page]. Cornell Hotel and Restaurant Administration Quarterly 28:8.

\section{Bio}

Alex M. Susskind, Ph.D., is an associate professor at the Cornell University School of Hotel Administration (ams76@cornell.edu). 